\title{
Biological evaluation of mechanically deboned chicken meat protein hydrolysate 1
}

\author{
Avaliação biológica do hidrolisado de \\ proteina da carne de galinha \\ desossada mecanicamente
}

Daniele Misturini ROSSI2

Simone Hickmann FLÔRES²

Janaína Guimarães VENZKE ${ }^{3}$

Marco Antonio Záchia AYUB2

A B S T R A C T

\section{Objective}

The objective of this study was to evaluate the biological properties of a protein hydrolysate obtained by enzymatic hydrolysis of mechanically deboned chicken meat.

\section{Methods}

Mechanically deboned chicken meat was hydrolysed using Alcalase 2.4 L FG and then dried in a spray-drier. Three groups $(n=6)$ of male Wistar rats received diets containing casein, mechanically deboned chicken meat protein hydrolysate and a protein-free diet. The rats were randomly assigned to individual cages with controlled temperature $\left(22^{\circ} \mathrm{C}\right)$ for 12 days.

\section{Results}

The mechanically deboned chicken meat diet resulted in a good net protein utilization (3.74) and high true digestibility (96\%). The amino acid composition of the hydrolysate was relatively well balanced, but the concentrations of methionine and cystine were low, making them the limiting amino acids. The proximate chemical composition of the hydrolysate showed protein content to be as high as $62 \%$.

\section{Conclusion}

The results obtained in this work suggest that mechanically deboned chicken meat hydrolysate can be used as a protein enhancer in food preparations such as enteral formulations, and as an edible protein enhancer in general applications.

Indexing terms: Biological factors. Hydrolyzed vegetable protein. Protein. Epidemilogy, experimental.

\footnotetext{
1 Article based on the dissertation thesis by D.M. ROSSI, entitled "Utilização de carne mecanicamente separada de frango para produção de um hidrolisado protéico a partir de enzimas microbianas" (Use of mechanically deboned chicken meat to produce a protein hydrolysate using microbial enzymes). Universidade Federal do Rio Grande do Sul; 2007. Sponsored by Conselho Nacional de Desenvolvimento Científico e Tecnológico (Process number 505861/2004-6).

2 Universidade Federal do Rio Grande do Sul, Instituto de Ciência e Tecnologia de Alimentos. Av. Bento Gonçalves, 9500,

91501-970, Porto Alegre, RS, Brasil. Correspondência para/Correspondence to: D.M. Rossi.E-mail: <mazayub@ufrgs.br>.

3 Universidade Federal do Rio Grande do Sul, Departamento de Medicina Interna. Porto Alegre, RS Brasil.
} 
880 | D.M. ROSSI et al.

\section{RE S U M O}

\section{Objetivo}

O objetivo do estudo foi avaliar a qualidade biológica da proteína hidrolisada obtida a partir da carne mecanicamente separada de frango.

\section{Métodos}

A carne mecanicamente separada de frango foi hidrolisada com a enzima Alcalase 2,4 L FG e o hidrolisado obtido foi submetido a secagem em atomizador. Foram utilizados três grupos $(n=6)$ de ratos machos Wistar os quais receberam dietas contendo caseína, proteína hidrolisada de carne mecanicamente separada de frango ou uma dieta com proteína livre. Os animais foram distribuidos aleatoriamente em gaiolas individuais, com temperatura controlada $\left(22^{\circ} \mathrm{C}\right)$, por um período de 12 dias.

\section{Resultados}

A dieta utilizando carne mecanicamente separada de frango resultou em elevada utilização líquida de proteína $(3,74)$ e elevada digestibilidade verdadeira (96\%). A composição de aminoácidos da proteína hidrolisada apresentou bons resultados, embora metionina e cistina tenham apresentado baixos valores, sendo considerados aminoácidos limitantes. A composição química mostrou altos valores de proteína no hidrolisado obtido (62\%).

\section{Conclusão}

Os resultados obtidos neste trabalho sugerem que a proteína hidrolisada de carne mecanicamente separada de frango poderá ser utilizada como um suplemento em formulações alimentares, tais como formulações enterais, ou como fonte de complementação protéica na indústria de alimentos em geral.

Termos de indexação: Fatores biológicos. Proteína hidrolisada vegetal. Proteína. Estudos experimentais.

\section{N T RO D U C T IO N}

Brazil is the world's third largest chicken meat producer and the leading exporter of chicken products, with a total production of 9.7 millions tons in $2007{ }^{1}$. It is reckoned that at least $20 \%$ of chicken fresh-cut carcasses are transformed into Mechanically Deboned Chicken Meat (MDCM), which could be used in processed meats, such as meat emulsion, paste meat and chicken nuggets ${ }^{2}$. MDCM is a by-product of the poultry industry increasingly used in processed meat products. It is also a source of high biological quality proteins that could be used to produce protein preparations with specific characteristics. MDCM is mostly obtained from necks and back parts of chicken and turkey carcasses ${ }^{3}$.

Protein hydrolysates constitute a promising alternative to intact proteins and elemental formulas in the development of special formulations designed to provide nutritional support for patients with different needs ${ }^{4}$. The number of amino acid residues remaining in the peptide chains after hydrolysis is an essential characteristic in the production of protein hydrolysates with desired functional properties ${ }^{5}$. Protein hydrolysates find applications mainly in the nutritional management of individuals who cannot digest whole/intact protein. The most prevalent application of protein hydrolysates has been in formulations for infants with food hypersensitivity, in order to improve nutritional and functional properties ${ }^{6}$. Other possible applications of hydrolysates have been suggested and include the preparation of geriatric products, high energy supplements and weight control and therapeutic or enteric diets ${ }^{7}$.

The protein hydrolysates most commonly used in nutritional products are casein, whey protein and soy protein. Other sources of protein hydrolysates, such as fish, chickpea, shark muscle, and shrimp, were studied and can also be used in supplementation diets, high protein sports drinks, and therapeutic or enteric diets ${ }^{8-10}$. Considerable attention has been given to the use of MDCM as an ingredient in the manufacture of sausages and other meat products ${ }^{11}$, especially considering its nutritional quality ${ }^{2,12,13}$. However, few studies have 
been published on the production and quality of MDCM protein hydrolysate. The aims of this work were to study the biological quality of MDCM protein hydrolysate and its amino acid composition in order to use it as a nutritional enhancer in food products and diets.

\section{METHODS}

Mechanically deboned chicken meat was supplied by Avipal S.A, which is a large, local poultry processing plant. The enzyme used was Alcalase 2.4L FG, an endopeptidase from Bacillus licheniformis, provided by Novozymes Latin America, Brazil.

Batches of $8 \mathrm{~L}$ of MDCM were hydrolyzed in optimum conditions using Alcalase $\left(50^{\circ} \mathrm{C}, \mathrm{pH}\right.$ 8.0 and enzyme concentration of $2.0 \%$ ). The hydrolysate obtained was centrifuged at $8 \mathrm{~g}$ for $10 \mathrm{~min}$ (Sorvall RC-5B, Du Pont Instruments, USA) and concentrated to $20 \%$ of solids in a rotavap (Labortora, Heidolph 400, Germany). The hydrolysate was spray-dried in a laboratory spray-dryer (Model Mini Spray Dryer Buchi B 191, Sweden) with an inlet temperature of $160^{\circ} \mathrm{C}$, outlet temperature of $96^{\circ} \mathrm{C}$ and feed flow rate of $160 \mathrm{~mL} . \mathrm{h}^{-1}$, using $5 \%$ of maltodextrin as a carrier and $1 \%$ of calcium carbonate as anti-humectant agent.
The samples of MDCM and protein hydrolysate were collected and analyzed for moisture, ash, total fat ${ }^{14}$ and crude protein content $(\mathrm{N} \times 6.25)$ by the Kjeldahl method ${ }^{14}$.

Young, 21-23 days old, white male Wistar rats, weighing $40.0-55.0 \mathrm{~g}$, were obtained from the nursery of the Centro de Ciências Biológicas, Universidade Federal do Rio Grande do Sul, Brazil. Animals were randomly divided into three groups, each group consisting of 6 rats. Protein-free diets were offered to the first group. The second group was fed a casein diet as control. The third group received a protein hydrolysate diet. All animals received diets formulated with casein supplementation during an acclimation period of 2 days. The diets were formulated according to Reeves et al. ${ }^{15}$, adapted to contain $10 \%$ of protein for casein (control) and for MDCM protein hydrolysate. The diet compositions are listed in Table 1. Water and feed were offered ad libitum. The animals were individually caged and kept in a room at $22^{\circ} \mathrm{C}$ and a $12 \mathrm{~h}$ light and dark cycle. Feces were collected five times for each rat for a period of ten days. The feces were dehydrated, weighed and their nitrogen content was analyzed by the Kjeldahl method ${ }^{14}$.

Amino acid composition was determined after acid hydrolysis with $6 \mathrm{~N} \mathrm{HCl}$ for 24 hours at $110^{\circ} \mathrm{C}$, following methodology described by Spackman et al. ${ }^{16}$, using a Beckman HPLC-amino

Table 1. Calculated composition of the experimental diets as $10 \%$ protein of the total. Porto Alegre (RS), Brazil, 2007.

\begin{tabular}{lccc}
\hline \multirow{2}{*}{ Ingredients } & Casein & Protein-free diet & Protein hydrolysate \\
\cline { 2 - 4 } Casein & 11.86 & - & - \\
MDCM protein hydrolysate & - & - & 17.10 \\
Sucrose & 10 & 7 & 10 \\
Corn oil & 7 & 5 & 7 \\
Cellulose & 5 & 3.5 & 5 \\
Mineral mix & 3.5 & 1.0 & 3.5 \\
Vitamin mix & 1.0 & - & 1.0 \\
L-cystine & 0.3 & - & - \\
Choline bitartrate & 0.25 & 0.0014 & - \\
Tert-Butylhydroquinone & 0.0014 & 73.50 & 0.0014 \\
Cornstarch & 61.08 & & 56.40 \\
\hline
\end{tabular}

MDCM: mechanically deboned chicken meat. 
acid analyzer. Tryptophan was analyzed according to Spies ${ }^{17}$.

The data obtained from this experiment were used to calculate True Digestibility (TD) (Eq.1) and Net Protein Retention (NPR) (Eq.2) by employing the following formulas, according to Sgarbieri18: TD $=\left(\left(\mathrm{Ni}-\mathrm{NF}_{1}-\mathrm{NF}_{2}\right) / \mathrm{Ni}\right) \times 100$ (1) Where: $\mathrm{Ni}=$ Nitrogen intake of animals fed the tested diet; $N_{F 1}=$ Nitrogen excreted in feces of animals fed the tested diet; $\mathrm{N}_{\mathrm{F} 2}=$ Nitrogen excreted in feces of animals fed the protein-free diet.

$\mathrm{NPR}=$ weight gain of test group + weight loss of protein-free group / weight of test protein consumed.

Feed intake, protein intake and body weight were used to compute the following nutritional indices according to Sogi et al. ${ }^{19}$ showed in equations 3 to 5 :

Feed efficiency $(F E)$ = Gain in body wt (g)/Feed intake (g)

Feed utilization $(\mathrm{FU})=$ Feed intake $(\mathrm{g}) / \mathrm{Gain}$ in body wt (g)

Protein utilization $(\mathrm{PU})=$ Protein intake (g)/Gain in body wt (g)

The data were subjected to Analysis of Variance (ANOVA) in a completely randomized design to determine the significant differences among the various groups.

\section{RESULTS AND DISCUSSION}

\section{Proximate chemical composition}

The chemical composition of mechanically deboned chicken meat and its spray-dried hydrolysate is presented in Table 2. MDCM presented much higher fat and lower protein contents. The high amounts of fats in the MDCM might indicate a process where more skin offproducts are being used, while the unusually low ash content is indicating that less bones and cartilaginous tissues were used. The fat content in the hydrolysate was greatly reduced during the
Table 2. Proximate composition of mechanically deboned chicken meat and the spray-dried hydrolysate. Porto Alegre (RS), Brazil, 2007.

\begin{tabular}{lcccccc}
\hline \multirow{2}{*}{ Composition (\%) } & \multicolumn{2}{c}{ MDCM $^{\mathbf{a}}$} & & \multicolumn{2}{c}{ Spray-dried hydrolysate } \\
\cline { 2 - 3 } \cline { 5 - 6 } & M & SD & & M & SD \\
\hline Moisture & 63.65 & 3.57 & & 6.92 & 0.17 \\
Proteinc & 32.56 & 1.07 & & 61.93 & 1.10 \\
Fatc $^{c}$ & 55.58 & 1.08 & & 1.08 & 0.30 \\
Ash $^{c}$ & 2.15 & 0.05 & & 30.07 & 0.06 \\
\hline
\end{tabular}

avalues are means and standard deviations of quintuplicate measurements; bValues obtained using $5 \%$ of maltodextrin as a carrier for spray drying. Values are means of duplicate measurements; 'Dry weight basis.

MDCM: mechanically deboned chicken meat; M: mean; SD: standard deviation.

exclusion of the insoluble protein fraction by centrifugal separation ${ }^{20}$. Spray-dried hydrolysate showed very high protein content (61.9\%). Comparatively, Hamid et al. ${ }^{21}$, used $2.0 \%$ Alcalase, $\mathrm{pH} 8.0$ and $55^{\circ} \mathrm{C}$ to produce fish protein hydrolysate powder with $49.6 \%$ of total protein and $2.8 \%$ of fat, while Soares et al. ${ }^{22}$, using Alcalase at $1.2 \%, \mathrm{pH} 7.0$ and $50^{\circ} \mathrm{C}$ to hydrolyze mechanically deboned chicken meat, obtained around $40.5 \%$ of total protein after the spraydrying process.

\section{Nutritional indices}

The protein hydrolysate showed good nutritional quality when compared with casein. Table 3 shows the nutritional indices obtained in the biological assay. Rats fed casein, with a total consumption of $107.08 \mathrm{~g}$ of feed, gained less weight than those fed protein hydrolysate (total consumption of $100.96 \mathrm{~g}$ of feed, although these results were not significantly different $(p<0.05)$. Protein intake, feed efficiency, feed utilization and protein utilization were not significantly different $(p<0.05)$ when compared with casein.

Digestibility is the measure of the percentage of proteins that are hydrolyzed by digestive enzymes and absorbed as amino acids by the organism, and it determines the protein quality of the diet. The compared digestibility of 
Table 3. Nutritional indices* of casein and protein hydrolysate diets. Porto Alegre (RS), Brazil, 2007.

\begin{tabular}{|c|c|c|c|c|}
\hline \multirow{2}{*}{ Parameter* } & \multicolumn{2}{|c|}{ Casein } & \multicolumn{2}{|c|}{ Protein hydrolysate } \\
\hline & M & SD & M & SD \\
\hline Feed intake (g) & 107.08 & 19.38 & 100.96 & 21.48 \\
\hline Initial weight (g) & 46.25 & 2.36 & 52.32 & 2.72 \\
\hline Weight gain (g) & 34.47 & 9.45 & 35.46 & 15.82 \\
\hline Protein utilization & 0.36 & 0.24 & 0.31 & 0.14 \\
\hline NPR & 3.21 & 4.18 & 3.74 & 6.77 \\
\hline TD (\%) & $97.64^{\mathrm{a}}$ & 0.74 & $96.43^{b}$ & 0.68 \\
\hline
\end{tabular}

*Values are means and standard deviations of 6 rats per group over an experimental period of 10 days; ${ }^{a, b}$ Different superscripts are significantly different $(p<0.05)$ according to the Student's $t$ test.

M: mean; SD: standard deviation; NPR: net protein retention; TD: true digestibility.

protein hydrolysate $(96.43 \%)$ and casein $(97.74 \%)$ were proximately the same, indicating that protein hydrolysate is exceptionally good as a source of amino acids, rendering highly digestible protein meals. The Net Protein Ratio method estimates the protein used for growth and maintenance. The NPR value of protein hydrolysate (3.74) was greater than that of casein (3.21), although not significantly different $(p<0.05)$. Our results showed that MDCM protein hydrolysate, as prepared in this work, was a much better source of protein when compared with other preparations listed in the literature. Rebeca et al. ${ }^{23}$, who used eviscerated mullet to produce fish protein hydrolysate, found NPR values of 3.07. Negrão et al. ${ }^{2}$, using mechanically deboned chicken flour, reported NPR values of 3.19 and true digestibility of $92.90 \%$, which was lower than that of MDCM protein hydrolysate, suggesting that hydrolysis can contribute to better digestibility because its absorption by the organism might be more effective.

\section{Amino acid composition}

The nutritional value of dietary proteins is determined by the pattern and quantity of essential amino acids present. The presence of one or more of the essential amino acids in adequate amounts increases the nutritive value of the protein ${ }^{24}$. The quality of MDCM protein hydrolysate as source of amino acids can be assessed by comparing the essential amino acids with the World Health Organization's (WHO) ${ }^{25}$ recommended standard, and is shown in Table 4. The amino acid profile of the mechanically deboned chicken meat protein hydrolysate contained higher amounts of all essential amino acids, except for methionine and cystine when compared with the WHO's reference for adults. Considering the demands for children (2-5-year-olds), the results indicated that MDCM protein hydrolysate contained adequate amounts of lysine, treonine, isoleucine and histidine ${ }^{25}$. The low concentrations of methionine and cystine are reported not only in animal proteins, which are generally considered reference proteins, but also in vegetable sources, normally lacking sulfur amino acids ${ }^{18}$. This low content of methionine and cystine can be increased by adding other food ingredients containing high or moderate amounts of sulfur amino acids or by supplementing L-methionine to the formulation, especially when used for infants. However, a good protein needs more than just containing amino acids in adequate proportions to meet all the requirements of an organism. The amino acids also need to have high bioavailability, i.e., they can be absorbed in a metabolic active form, in order to achieve specific functions in the body. Despite the relatively low amounts of methionine and cystine in MDCM protein hydrolysate, animals in our study had good 
884 | D.M. ROSSI et al.

Table 4. Amino acid composition of mechanically deboned chicken meat (MDCM) protein hydrolysate. Porto Alegre (RS), Brazil, 2007.

\begin{tabular}{|c|c|c|c|}
\hline Amino acid & Protein hydrolysate (mg/g protein) & FAO (2-5 years) & FAO (adults) \\
\hline \multicolumn{4}{|l|}{ Essential } \\
\hline Histidine & 24 & 19 & 16 \\
\hline Isoleucine & 34 & 28 & 13 \\
\hline Leucine & 62 & 66 & 19 \\
\hline Lysine & 70 & 58 & 16 \\
\hline Metionine+Cystine* & 15 & 25 & 17 \\
\hline Phenylalanine+Tyrosine & 65 & 63 & 19 \\
\hline Treonine & 38 & 34 & 5 \\
\hline Tryptophan & 9 & 11 & 9 \\
\hline Valine & 36 & 35 & 13 \\
\hline \multicolumn{4}{|l|}{ Non essential } \\
\hline Aspartic acid & 86 & - & - \\
\hline Glutamic acid & 128 & - & - \\
\hline Serine & 36 & - & - \\
\hline Proline & 37 & - & - \\
\hline Glycine & 48 & - & - \\
\hline Alanine & 50 & - & - \\
\hline Arginine & 54 & - & - \\
\hline
\end{tabular}

*limiting amino acid. MDCM: mechanically deboned chicken meat; FAO: Food and Agriculture Organization.

weight gain and the NPR and the true digestibility of MDCM protein hydrolysate values were excellent, suggesting that the amino acids were promptly available for digestion, rendering this source as adequate.

\section{CONCLUSION}

Proximate analyses revealed that the spraydried mechanically deboned chicken meat protein hydrolysate consisted of proximately $62 \%$ protein and very low lipid content, characteristics that are usually desired for food preparations with special ends such as diets for weight control, enteral nutrition, among others. Biological parameters indicated that protein hydrolysate, a low-cost product, presented very good nutritional properties, despite its low content of methionine and cystine, the limiting amino acids. Protein hydrolysate could be used in industrial preparations and specialized adult nutritional products and supplements and, when supplemented with the limiting amino acids, its use could be tested in infant formulas.

\section{ACKNOWLEDGEMENTS}

The authors wish to thank Avipal Alimentos S.A., for supplying the mechanically deboned chicken meat and Conselho Nacional de Desenvolvimento Científico e Tecnológico for sponsoring this study.

\section{COLLABORATORS}

D.M. ROSSI participated in all the stages of the study. J.G. VENZKE helped with the animal experiments and enzymatic hydrolysis of the mechanically deboned chicken meat. S.H. FLÔRES co-supervised the study, following all the stages. M.A.Z. AYUB supervised and coordinated the project and wrote the manuscript.

\section{REFERE N CES}

1. Associação Brasileira de Exportadores de Frango. Produção mundial de carne de frango. 2007 [acesso 20075 Sept]. Disponível em: <http:// www.abef.com.br/estatisticas/mercadomundial/ mercadomundial/php $>$.

2. Negrão CC, Mizubuti IY, Morita MC, Colli C, Ida El, Shimokomaki M. Biological evaluation of mechanically deboned chicken meat protein 
quality. Food Chem. 2005; 90(4):579-83. doi:10.10 16/j.foodchem.2004.05.017.

3. Froning GW. Mechanical deboned of poultry and fish. New York: Advances in Food Research Academic Press; 1981.

4. Clemente A. Enzymatic protein hydrolysates in human nutrition. Trends Food Sci Technol. 2000; 11(7):254-62. doi:10.1016/S0924-2244(01)00 007-3.

5. Xia SH, Wang Z, Xu SY. Characteristics of Bellamya purificata snail foot protein and enzymatic hydrolysates. Food Chem. 2007, 101(3); 101:118896. doi:10.1016/j.foodchem.2006.03.031.

6. Mahmoud MI. Physicochemical and functional properties of protein hydrolysates in nutritional products. Food Technol. 1994; 48(10):89-5.

7. Frokjaer $S$. Use of hydrolysates for protein supplementation. Food Technol. 1994; 48(10):86-8.

8. Clemente A, Vioque J, Sanchéz-Vioque R, Pedroche J, Bautista J, Millán F. Protein quality of chickpea (Cicer arietinum L.) protein hydrolysates. Food Chem. 1999; 67(3):269-74. doi:10.1016/S030 8-8146(99)00130-2.

9. Simpson BK, Nayeri G, Yalayan V, Ashie INA. Enzymatic hydrolysis of shrimp meat. Food Chem. 1998; 61(1-2):131-8. doi:10.1016/S0308-8146 (97)00131-3.

10. Guérard F, Dufossé L, De La Broise D, Binet A. Enzymatic hydrolysis of proteins from yellowfin tuna (Thunnus albacares) wastes using Alcalase. J Mol Catal B: Enzym. 2001; 11(4-6):1051-59. doi: 10.1016/S1381-1177(00)00031-X.

11. Mielnik MB, Aaby K, Rolfsen K, Ellekjaer MR, Nilsson A. Quality of comminuted sausages formulated from mechanically deboned poultry meat. Meat Sci. 2002; 61(1):73-4. doi:10.1016/ S0309-1740(01)00167-X.

12. Essary EO. Moisture, fat, protein and mineral content of mechanically deboned poultry meat. J Food Sci. 1979; 44(4):1070-3. doi:10.1111/j.136 5-2621.1979.tb03449.

13. Tanaka MCY, Shimokomaki M. Collagen types in mechanically deboned chicken meat. J Food Biochem. 1996; 20(3):215-25. doi:10.1111/j.174 5-4514.1996.tb00552.

14. Association of Official Analytical Chemists. Official methods of analysis. Washington (DC): AOAC; 1990.

15. Reeves PG, Forrest HN, Fahey GCJ. AIN-93 Purified diets for laboratory rodents: Final report of the
American Institute of Nutrition ad hoc writing committee on the reformulation of the AIN-76A rodent diet. J Nutr. 1993; 123(11):1939-51.

16. Spakman DH, Stein WH, Moore S. Automatic recording apparatus for use in the chromatography of amino acids. Anal Chem. 1958; 30(7):1190-206. doi: 10.1021/ac60139a006.

17. Spies JR. Determination of tryptophan in proteins. Anal Chem. 1967; 39(10):1412-5.

18. Sgarbieri VC. Proteínas em alimentos protéicos: propriedades, degradações, modificações. São Paulo: Varela; 1996.

19. Sogi DS, Bhatia R, Garg SK, Bawa AS. Biological evaluation of tomato waste seed meals and protein concentrate. Food Chem. 2005; 89(1):53-6 doi: 10.1016/j.foodchem.2004.01.083.

20. Shahidi F, Han XQ, Synowiecki J. Production and characteristics of protein hydrolysates from capelin (Mallotus villosus). Food Chem. 1995; 53(3):285-93. doi:10.1016/0308-8146(95)93934-J.

21. Hamid A, Bakar J, Bee GH. Nutritional quality of spray dried protein hydrolysate from Black Tilapia (Oreochromis mossambicus). Food Chem. 2002; 78(1):69-4. doi:10.1016/\$0308-8146(01)00380-6.

22. Soares LHB, Marques DN, Albuquerque PM, Ayub MAZ. Influence of some commercial proteases and enzymatic associations on the hydrolytic solubilization of deboned poultry meat proteins. Food Sci Technol Int. 2000; 6(4):301-6. doi: 10.11 77/108201320000600404.

23. Rebeca BD, Peña-Vera MT, Díaz-Castañeda M. Production of fish protein hydrolysates with bacterial proteases; yield and nutritional value. J Food Sci. 1991; 56(2):309-14. doi: 10.1111/j.13 65-2621.1991.tb05268.

24. Rangel A, Saraiva K, Schwengber P, Narciso MS, Domont GB, Ferreira ST, et al. Biological evaluation of a protein isolate from cowpea (Vigna unguiculata) seeds. Food Chem. 2004; 87(4):491-9. doi:10.10 16/j.foodchem.2003.12.023.

25. Food and Agriculture Organization. Energy and protein requirements. Report of a joint FAONHO/ UNU Expert Consultation. World Health Organization. Geneve: World Health Organization; 1985. Technical Report Series 724.

Received on: 13/12/2007

Final version resubmitted on: 12/8/2008 Approved on: 9/2/2009 